УДК $378.091 .33: 004.92(045)$

Матвійчук-Юдіна Олена Василівна

старший викладач, пошукач кафедра комп'ютерних мультимедійних технологій

Національний авіаційний університет, м. Київ, Україна

ORCID ID 0000-0002-5906- 5023

metalen3@ukr.net

\title{
ВІТЧИЗНЯНИЙ ТА ЗАРУБІЖНИЙ ДОСВІД ФОРМУВАННЯ ЗМІСТУ НАВЧАННЯ КОМП'ЮТЕРНОЇ ГРАФІКИ МАЙБУТНІХ БАКАЛАВРІВ КІБЕРБЕЗПЕКИ
}

\begin{abstract}
Анотація. У статті визначено і проаналізовано особливості формування змісту навчальної дисципліни «Комп'ютерна графіка» в процесі професійної підготовки бакалаврів кібербезпеки. здійснено порівняльний аналіз контенту освітніх планів, навчальних i робочих програм підготовки бакалаврів кібербезпеки вищих навчальних закладів України, Польщі, Казахстану та Росії. Аналіз світового досвіду засвідчує, що підготовка висококваліфікованих кадрів рівня бакалавра у цілому орієнтована на створення сприятливих умов для формування фахових компетентностей для вирішення широкого спектра виробничих завдань, не зважаючи на те, що освітня діяльність кожної країни спирається на власну систему стандартизації, нормативно-правового й економічного забезпечення 3 урахуванням напрямів використання спеціалістів згідно потреб того чи іншого ринку праці і послуг. Результати дослідження можуть слугувати підгрунтям для визначення змісту навчально-методичного комплексу з предмету «Комп’ютерна графіка», що має бути орієнтованим на розгляд таких тем: формати і методи компресії цифрових образів, стеганографічні методи захисту інформації в сучасних графічних форматах, голографія і т. п., вивчення яких максимально сприятиме формуванню професійних компетентностей майбутніх бакалаврів кібербезпеки.
\end{abstract}

Ключові слова: контент навчально-методичного комплексу; навчальна програма; професійні компетентності; інтегрована компетентність; фахівці 3 інформаційних технологій і кібербезпеки; комп’ютерна графіка.

\section{1. ВСТУП}

Постановка проблеми. Широкими кроками в Україні відбуваються нормативноправові, економічні, наукоємні, технологічні та інші зміни, визначено нові пріоритетні напрями державної політики в галузі інформаційних технологій (IT). Підготовка фахівців різних кваліфікаційних рівнів і розробка нових стандартів навчання галузі IT освіти є одним із базових завдань вищого навчального закладу (ВН3) в умовах розвитку будь-якої країни світу.

Означені процеси потребують формування у майбутніх бакалаврів IT спеціальностей нових практичних умінь, знань та навичок. Бурхливу інтеграцію IT технологій у комунікаційні взаємозв'язки суспільства і держави неможливо уявити без сучасних систем відображення інформації, а саме без різних видів комп'ютерної графіки.

Аналіз останніх досліджень i публікацій. Проблеми змісту i сутності професійної підготовки майбутніх фахівців IT-сфери у системі вищої школи знайшли своє відображення у науковому доробку провідних українських учених у галузі інформаційно-комунікаційних технологій в освіті: В. Биков, А. Васильєв, А. Гуржій, М. Жалдак, М. Згуровський, Ю. Зубань,Ю. Коровайченко, В. Кухаренко, А. Манако, О. Меняйленко, Н. Морзе, В. Олійник, Є. Полат, С. Раков, О. Співаковський, О. Спірін, С. Семеріков, Ю. Триус, С. Шкарлет та ін. 
Особливої уваги у контексті досліджуваної проблеми варті праці вітчизняних науковців С. Горобець, В. Мироненка, М. Новожилова, Н. Федотової та ін., безпосередньо присвячені проблемі викладання комп’ютерної графіки.

У руслі окресленої проблематики проаналізовано праці зарубіжних науковців, присвячені дослідженню проблем формування навчального контенту предметів, спрямованих на вивчення інформаційно-комунікаційних технологій (IКT) у вищій школі: I. Аллен (I Allen), К. Блертона (C. Blurton), X. Вонг (H. Wang),Л. Ларсона (L. Larson), Д. Сіамен (J. Seaman), К. Цуі (X. Cui), Д. Хелмер (J. Helmer) та ін. 3 огляду на тему дослідження суттєвий інтерес викликає кандидатська дисертація російської дослідниці Т. Чернякової, у якій розкривається методика навчання комп'ютерної графіки студентів у ВНЗ і, зокрема, спеціальності 030500.06 «рофесійне навчання (інформатика, обчислювальна техніка та комп'ютерні технології)». Праці зарубіжних учених важливі для нашого дослідження з погляду порівняння й оцінювання.

Сучасні вчені одностайні в думці, що вивчення комп'ютерної графіки на сьогоднішній день $є$ одним із найважливіших компонентів вищої професійної освіти в таких галузях, як кіно, архітектура, мистецтво і т. п. Проте вчені констатують, що постійно з'являються нові сфери застосування комп'ютерної графіки, отже, відповідно, зростає значимість досліджень наявного вітчизняного і зарубіжного досвіду реалізації підготовки майбутніх спеціалістів 3 розвиненими вміннями комп'ютерного моделювання і візуалізації для таких специфічних спеціальностей, як, наприклад «кібербезпека». Аналіз наукових праць, які безпосередньо чи опосередковано стосуються досліджуваної проблеми, показав, що спеціальні дослідження, у яких би вирішувалися питання навчання комп'ютерної графіки майбутніх бакалаврів кібербезпеки, практично відсутні.

Мета статті - здійснити порівняльний аналіз контенту освітніх планів, навчальних і робочих програм спеціальності «Кібербезпека» вітчизняних і зарубіжних вищих навчальних закладів і визначити особливості формування контенту з предмету «Комп’ютерна графіка» для майбутніх бакалаврів кібербезпеки.

\section{2. РЕЗУЛЬТАТИ ДОСЛІДЖЕННЯ}

\section{Місце предмету комп'ютерна графіка в загальній системі формування кометентностей бакалаврів в Україні й за кордоном.}

Сучасні умови розвитку держави i суспільства вимагають максимально забезпечити відповідність контенту підготовки спеціалістів динамічному зростанню вимог світового інформаційного суспільства $[1,2]$. А отже, серед першочергових задач вищої школи постає завдання поставити у відповідність компетентності, які мають набути студенти в результаті реалізації освітніх процесів ВН3, і контенти предметів, у процесі вивчення яких формується майбутній професіонал.

Зрозуміло, що вітчизняна освіта повинна адаптуватися до Свропейських i світових вимог і стандартів підготовки кадрів. Окреслене питання неможливо вирішити без прагнення ВНЗ країни синтезувати освітні плани та навчальні й робочі програми підготовки IT бакалаврів у загально-концептуальному підході й у сенсі конкретизації певного переліку лекційного і практичного матеріалу. Створюючи освітні програми, треба чітко уявляти перелік компетентностей фахівця відповідно до сектору індустрії і системи ринкових відносин [3].

Курс «Комп'ютерна графіка» навчальної програми професійної підготовки майбутніх бакалаврів кібербезпеки відповідно до стандарту «125. Кібербезпека» спрямований на розвиток таких фахових компетентностей (КФ): 
- КФ 2. Здатність до використання інформаційно-комунікаційних технологій, сучасних архітектур, методів і моделей безпеки з метою передачі, зберігання, обробки та висвітлення електронних інформаційних ресурсів в інформаційних та інформаційно-телекомунікаційних (автоматизованих) системах;

- КФ 3. Здатність до використання програмних i програмно-апаратних комплексів захисту електронних інформаційних ресурсів в інформаційних та інформаційно-телекомунікаційних (автоматизованих) системах на основі сучасних наукоємних технологій, а також методів і моделей інформаційної безпеки та / або кібербезпеки;

- КФ 4. Здатність формувати та впроваджувати системи управління доступом, а також здійснювати протидію несанкціонованим вторгненням до електронних інформаційних ресурсів та процесів в інформаційних та інформаційнотелекомунікаційних (автоматизованих) системах згідно встановленої політики безпеки;

- КФ 5. Здатність забезпечувати захист інформаційних потоків даних в інформаційно-телекомунікаційних (автоматизованих) системах, а також безпосередньо в мережах передачі даних різних класів 3 метою реалізації встановленої політики безпеки та ін.

Наголосимо, що у провідних зарубіжних вищих навчальних закладах простежується загальна тенденція створення для реалізації процесів навчання сучасних інфраструктур разом з провідними компаніями країни та світу. Так, наприклад, система професійної підготовки в США, Німеччині, Польщі передбачає змістовний i поглиблений практико-професійний підхід через формування так званої компетентності «Робочого місця» (Індустріальна модель Кібербезпеки) [3]. Майбутні фахівці, окрім стандартних академічних точок контролю 3 предмету (залік, іспит тощо), мають підтвердити свої знання сертифікатами, які отримують на підприємствах. Студенти проходять практику у провідних організаціях і компаніях світу протягом 4-8 тижнів на рік 3 обов'язковим отриманням сертифікатів професійної атестації 3 конкретного предмету або сукупності предметів, серед яких і «Комп'ютерна графіка».

Як відомо, в Україні спостерігаємо інший підхід: навчальні предмети, під час вивчення яких формуються фахові компетентності, хоча і корелюють з різними видами практик, передбаченими навчальним планом, проте не відповідають ідеології професійної сертифікації. Можемо констатувати, що такий підхід зберігається практично для всього пострадянського сектору освіти.

У попередніх дослідженнях, автор зазначав, що у навчальних планах підготовки бакалаврів, як в Україні, так і в Польщі, Казахстані, Росії наявне викладання дисципліни «Інженерна та комп'ютерна графіка». Наприклад, для польських навчальних планів (4 семестр), присутня стандартна назва предмету: «Комп’ютерна графіка та комунікація людина - комп’ютер» («Grafika komputerowa i komunikacja człowiek-komputer») у складі стандартної кількості кредитів підготовки бакалаврів (240 кр.) [4].

Наголосимо, що у репрезентованій статті вищезазначені країни були обрані для аналізу не випадково, оскільки автор мав можливість особисто у процесі власної педагогічної діяльності ретельно ознайомитися 3 практикою викладання предмету «Комп'ютерна графіка» в Україні, Польщі, Казахстані та Росії. Водночас у попередніх дослідженнях автор детально досліджував компетентності фахівців з кібербезпеки на базі Індустріальної Моделі Кібербезпеки США [5].

Нижче наведено загальну таблицю порівняльного аналізу кількості годин викладання лекційних і лабораторних занять 3 дисципліни «Інженерна та комп'ютерна графіка» для аналізованих країн (табл. 1). 
Таблиияя 1

Порівняльний аналіз кількості годин викладання лекційних і лабораторних занять 3 дисципліни «Інженерна та комп'ютерна графіка»

\begin{tabular}{|c|c|c|c|c|c|}
\hline \multirow[b]{2}{*}{ Країна } & \multirow[b]{2}{*}{$\begin{array}{c}\text { Галузь знань } \\
\text { (напрям } \\
\text { підготовки) }\end{array}$} & \multirow[b]{2}{*}{$\begin{array}{c}\text { Всього } \\
\text { навчальних } \\
\text { годин } 3 \\
\text { дисципліни }\end{array}$} & \multicolumn{2}{|c|}{ Аудиторні заняття } & \multirow[b]{2}{*}{$\begin{array}{c}\text { Самостійна } \\
\text { робота }\end{array}$} \\
\hline & & & $\begin{array}{l}\text { Кількість } \\
\text { лекційних } \\
\text { годин }\end{array}$ & $\begin{array}{c}\text { Кількість } \\
\text { лабораторних } \\
\text { годин }\end{array}$ & \\
\hline Україна & $\begin{array}{l}12 \text { - Інформаційні } \\
\text { технології. } \\
\text { Кібербезпека }\end{array}$ & 90 & 17 & 17 & 56 \\
\hline Росія & $\begin{array}{l}09.03 .00 \\
\text { Інформатика та } \\
\text { обчислювальна } \\
\text { техніка. } \\
\text { Інформаційна } \\
\text { безпека або захист } \\
\text { інформації в } \\
\text { інформаційно- } \\
\text { телекомунікаційних } \\
\text { системах }\end{array}$ & 144 & 32 & 32 & 80 \\
\hline Казахстан & $\begin{array}{l}\text { 5В070300 - } \\
\text { Інформаційні } \\
\text { системи. } \\
\text { Інформаційна } \\
\text { безпека або захист } \\
\text { інформації в } \\
\text { інформаційно- } \\
\text { телекомунікаційних } \\
\text { системах }\end{array}$ & 165 & 15 & 30 & $\begin{array}{c}120(\mathrm{CPC} 60 \backslash \\
\text { СРСB60) }\end{array}$ \\
\hline Польща & $\begin{array}{l}\text { Інформатика. } \\
\text { Безпека } \\
\text { інформаційних } \\
\text { систем (// Безпека } \\
\text { інформації та } \\
\text { інформаційних } \\
\text { систем) }\end{array}$ & 120 & 20 & 30 & 70 \\
\hline
\end{tabular}

Зазначимо, що у навчальному плані підготовки спеціалістів Казахстану в розділі «Самостійна робота студента» (СРС) встановлено кількість годин - 120 годин, які розподіляються на 60 годин - СРС та 60 годин самостійної роботи студент - викладач [6]. Зазначений вид занять передбачає On-Line консультації викладача за встановленим розкладом. Така форма освітнього процесу очевидно підвищує якість надбання знань, проте відсутня в українських ВНЗ.

Система підготовки IT фахівців таких Свроазійських країн, як Казахстан і Росія, на відміну від України та Польщі, не має розбіжностей у навчальних планах, що розміщені в електронно-інформаційному просторі $[7,8]$. У типових навчальних планах знаходимо багато спільного, і в той же час, немало розбіжностей у викладанні дисципліни «Комп'ютерна графіка» (Національний Авіаційний Університет, Університет ім. Т. Шевченка), «Начертательная геометрия и компьютерная графика» (Технічний Університет Астана, Казахстан) або «Комп'ютерна графіка та комунікація людина - комп’ютер» («Grafika komputerowa i komunikacja człowiek-komputer») (НП Університет Бельско-Бяла, Республіка Польща) та ін. [9]. 
Прерогативою збігів контенту в концептуальних підходах до формування лекційного матеріалу означеної дисципліни можна визначити Україна-Польща та РосіяКазахстан.

Нижче наведено загальну таблицю порівняльного аналізу тематик лекційних занять і відповідної їм кількості годин 3 дисципліни «Інженерна та комп’ютерна графіка» для аналізованих країн (табл. 2).

Таблиия 2

\section{Порівняльний аналіз тематики лекційних занять 3 дисципліни «Інженерна та комп'ютерна графіка»}

\begin{tabular}{|c|c|c|c|c|c|c|c|}
\hline \multicolumn{2}{|c|}{ Україна } & \multicolumn{2}{|l|}{ Росія } & \multicolumn{2}{|c|}{ Казахстан } & \multicolumn{2}{|l|}{ Польща } \\
\hline Назва лекції & $\begin{array}{l}\text { К-ть } \\
\text { год. }\end{array}$ & Назва лекції & $\begin{array}{l}\text { К-ть } \\
\text { год. }\end{array}$ & Назва лекції & $\begin{array}{l}\text { К-ть } \\
\text { год. }\end{array}$ & Назва лекції & $\begin{array}{l}\text { К-ть } \\
\text { год. }\end{array}$ \\
\hline- & - & - & - & $\begin{array}{l}\text { Графічна } \\
\text { система ПК }\end{array}$ & 1 & - & - \\
\hline- & - & - & - & $\begin{array}{l}\text { Комп'ютер для } \\
\text { роботи } 3 \\
\text { графікою } \\
\end{array}$ & 1 & - & - \\
\hline \multirow{2}{*}{$\begin{array}{l}\text { Основні } \\
\text { поняття } \\
\text { комп’ютерно } \\
\text { ї графіки }\end{array}$} & \multirow[b]{2}{*}{2} & \multirow{3}{*}{$\begin{array}{l}\text { Растрова та } \\
\text { векторна } \\
\text { графіка. } \\
\text { Малювання } \\
\text { основних } \\
\text { графічних } \\
\text { примітивів } \\
\text { пряма лінія, } \\
\text { окружність, } \\
\text { еліпс. Алгоритм } \\
\text { Брезенхейма }\end{array}$} & \multirow{3}{*}{4} & $\begin{array}{l}\text { Види } \\
\text { комп'ютерної } \\
\text { графіки. }\end{array}$ & 1 & \multirow[b]{2}{*}{$\begin{array}{l}\text { Grafika } \\
\text { wektorowa i } \\
\text { rastrowa }\end{array}$} & \multirow[b]{2}{*}{1} \\
\hline & & & & $\begin{array}{l}\text { Проекції. } \\
\text { Геометричні } \\
\text { перетворення } \\
\text { растрових } \\
\text { картин }\end{array}$ & 2 & & \\
\hline $\begin{array}{l}\text { Математичні } \\
\text { й } \\
\text { алгоритмічні } \\
\text { основи } \\
\text { двовимірної } \\
\text { графіки }\end{array}$ & 2 & & & $\begin{array}{l}\text { Координати і } \\
\text { перетворення }\end{array}$ & 2 & $\begin{array}{l}\text { Realizacja } \\
\text { podstawowych } \\
\text { transformacji - } \\
\text { translacja, obrót, } \\
\text { skalowanie }\end{array}$ & 2 \\
\hline \multirow{3}{*}{$\begin{array}{l}\text { Базові } \\
\text { растрові } \\
\text { алгоритми }\end{array}$} & \multirow{3}{*}{2} & \multirow{3}{*}{$\begin{array}{l}\text { Сплайни. } \\
\text { Визначення } \\
\text { сплайна. Криві } \\
\text { Безьє, } \\
\text { раціональні } \\
\text { кубічні } \\
\text { сплайни, Бета } \\
\text { сплайни }\end{array}$} & \multirow{3}{*}{6} & - & & $\begin{array}{l}\text { Krzywe sklejane } \\
\text { - splines }\end{array}$ & 1 \\
\hline & & & & - & & $\begin{array}{l}\text { Wielomiany } \\
\text { Bernsteina - } \\
\text { krzywe Beziera, } \\
\text { algorytm de } \\
\text { Casteljau }\end{array}$ & 2 \\
\hline & & & & - & & $\begin{array}{l}\text { Krzywe B- } \\
\text { sklejane (B- } \\
\text { splinses) }\end{array}$ & 1 \\
\hline $\begin{array}{l}\text { Математичні } \\
\text { й } \\
\text { алгоритмічні } \\
\text { основи } \\
\text { тривимірної } \\
\text { графіки }\end{array}$ & 3 & $\begin{array}{l}\text { Перетворення в } \\
\text { просторі. } \\
\text { Основи } \\
\text { перспективи. } \\
\text { Необхідні } \\
\text { відомості з } \\
\text { лінійної алгебри } \\
\text { та } \\
\text { аналітичної } \\
\text { геометрії }\end{array}$ & 8 & $\begin{array}{l}\text { Геометричне } \\
\text { моделювання }\end{array}$ & 1 & $\begin{array}{l}\text { Powierzchnie } \\
\text { parametryczne - } \\
\text { podstawowe } \\
\text { pojecia }\end{array}$ & 1 \\
\hline $\begin{array}{l}\text { Колірні } \\
\text { Моделі в } \\
\text { комп’ютерні } \\
\text { й графіці }\end{array}$ & 2 & - & - & - & - & $\begin{array}{l}\text { Przestrzenie barw } \\
\text { w grafice - RGB, } \\
\text { CMY, (CMYK), } \\
\text { HSV }\end{array}$ & 2 \\
\hline
\end{tabular}




\begin{tabular}{|c|c|c|c|c|c|c|c|}
\hline \multicolumn{2}{|c|}{ Україна } & \multicolumn{2}{|l|}{ Росія } & \multicolumn{2}{|l|}{ Казахстан } & \multicolumn{2}{|l|}{ Польща } \\
\hline Назва лекції & $\begin{array}{l}\text { К-ть } \\
\text { год. }\end{array}$ & Назва лекції & $\begin{array}{l}\text { К-ть } \\
\text { год. }\end{array}$ & Назва лекції & $\begin{array}{l}\text { К-ть } \\
\text { год. }\end{array}$ & Назва лекції & $\begin{array}{l}\text { К-ть } \\
\text { год. }\end{array}$ \\
\hline $\begin{array}{l}\text { Алгоритми } \\
\text { стиснення } \\
\text { даних }\end{array}$ & 2 & - & - & - & - & $\begin{array}{l}\text { Algorytmy } \\
\text { kompresji stratnej } \\
\text { i bezstratnej w } \\
\text { grafice } \\
\text { komputerowej. } \\
\text { Podstawowe } \\
\text { formaty graficzne } \\
\text { - JPG, GIF, PNG }\end{array}$ & 1 \\
\hline $\begin{array}{l}\text { Графічні } \\
\text { редактори та } \\
\text { формати } \\
\text { графічних } \\
\text { файлів }\end{array}$ & 2 & $\begin{array}{l}\text { Фільтри, і } \\
\text { фільтрація. } \\
\text { Цифрова } \\
\text { обробка } \\
\text { зображення. } \\
\text { Типи фільтрів - } \\
\text { згладжування } \\
\text { різкість, } \\
\text { контраст, } \\
\text { яскравість. } \\
\text { математичне } \\
\text { обгрунтування } \\
\text { побудови } \\
\text { фільтрів. } \\
\text { Градієнтні } \\
\text { фільтри. } \\
\text { Медіанні } \\
\text { фільтри. } \\
\text { Текстурування } \\
\end{array}$ & 6 & & & $\begin{array}{l}\text { Formaty zapisu i } \\
\text { kompresji } \\
\text { obrazów } \\
\text { rastrowych } \\
\text { (próbkowanie i } \\
\text { filtracja) oraz } \\
\text { zasady } \\
\text { matematycznego } \\
\text { opisu obrazów } \\
\text { wektorowych }\end{array}$ & 1 \\
\hline- & - & - & & $\begin{array}{l}\text { Заповнення } \\
\text { багатокутника і } \\
\text { заливка області }\end{array}$ & 1 & $\begin{array}{l}\text { Metody } \\
\text { wypełniania figur } \\
\text { - gradient, } \\
\text { tekstury } \\
\text { bitmapowe i } \\
\text { proceduralne, } \\
\text { mapowanie }\end{array}$ & 1 \\
\hline- & - & - & - & - & - & $\begin{array}{l}\text { Podstawy pracy z } \\
\text { warstwami }\end{array}$ & 1 \\
\hline- & - & \multirow{2}{*}{$\begin{array}{l}\text { Елементи } \\
\text { геометричної } \\
\text { оптики. Фізич- } \\
\text { не } \\
\text { обгрунтування. } \\
\text { Закони } \\
\text { відбивання, } \\
\text { заломлення } \\
\text { світла. } \\
\text { Розсіювання. } \\
\text { Закони Снелла і } \\
\text { Ламберта. Типи } \\
\text { світлових } \\
\text { джерел }\end{array}$} & \multirow[b]{2}{*}{2} & - & - & $\begin{array}{l}\text { Modele } \\
\text { oświetlenia - } \\
\text { Lamberta, } \\
\text { Phonga }\end{array}$ & 2 \\
\hline- & - & & & - & - & $\begin{array}{l}\text { Globalne } \\
\text { oświetlenie - } \\
\text { algorytmy } \\
\text { śledzenia } \\
\text { promieni (ray } \\
\text { tracing), metoda } \\
\text { energetyczna } \\
\text { (radiosity) }\end{array}$ & 2 \\
\hline \multirow{3}{*}{-} & \multirow{3}{*}{-} & \multirow{3}{*}{-} & - & $\begin{array}{l}\text { Генерація } \\
\text { векторів і кіл }\end{array}$ & 1 & \multirow{3}{*}{$\begin{array}{l}\text { Przesłanianie } \\
\text { figur - algorytm } \\
\text { wyznaczania linii } \\
\text { i powierzchni } \\
\text { zasłoniętych }\end{array}$} & \multirow{3}{*}{1} \\
\hline & & & - & $\begin{array}{l}\text { Видалення } \\
\text { прихованих } \\
\text { ліній і поверхонь }\end{array}$ & 2 & & \\
\hline & & & & $\begin{array}{l}\text { Відсікання } \\
\text { відрізків і }\end{array}$ & 2 & & \\
\hline
\end{tabular}




\begin{tabular}{|c|c|c|c|c|c|c|c|}
\hline \multicolumn{2}{|c|}{ Україна } & \multicolumn{2}{|l|}{ Росія } & \multicolumn{2}{|c|}{ Казахстан } & \multicolumn{2}{|l|}{ Польща } \\
\hline Назва лекції & $\begin{array}{l}\text { К-ть } \\
\text { год. }\end{array}$ & Назва лекції & $\begin{array}{l}\text { К-ть } \\
\text { год. }\end{array}$ & Назва лекції & $\begin{array}{l}\text { К-ть } \\
\text { год. }\end{array}$ & Назва лекції & $\begin{array}{l}\text { К-ть } \\
\text { год. }\end{array}$ \\
\hline & & & & багатокутників & & & \\
\hline- & - & - & - & - & - & $\begin{array}{l}\text { Algorytmy } \\
\text { cieniowania } \\
\text { Phonga, } \\
\text { Gourauda }\end{array}$ & 1 \\
\hline- & - & $\begin{array}{l}\text { Метод } \\
\text { випромінюван- } \\
\text { ня. Сучасні } \\
\text { напрямки } \\
\text { комп'ютерній } \\
\text { графіці }\end{array}$ & 8 & - & - & - & - \\
\hline- & - & - & - & $\begin{array}{l}\text { Реалістичне } \\
\text { представлення } \\
\text { сцен }\end{array}$ & 1 & - & - \\
\hline
\end{tabular}

Зазначимо, що у табл. 2 наведено перелік контенту лекційного матеріалу навчально-методичного комплексу Національного авіаційного університету, який розглядаємо як типовий для ВНЗ України, проте, як у наступних відомостях щодо Польщі, Казахстану та Росії наведено зведені дані більше ніж 24 різних вищих навчальних закладів.

Аналізуючи перелік контенту лекційного матеріалу згідно робочих програм, можна констатувати, що велика увага для професійної підготовки IT бакалаврів 3 дисципліни «Комп'ютерна графіка» в Україні й Польщі приділяється процесу навчання безпосередньо графічній складовій для опанування знаннями й уміннями відповідно до визначених компетентностей фахівця (зазначена дисципліна, входить до переліку обов'язкових і викладається в четвертому семестрі загальної підготовки бакалаврів). Підтвердженням цього висновку можуть слугувати лекційні заняття за темами: «Растрова та векторна графіка» - «Grafika wektorowa i rastrowa»; «Сплайни. Визначення сплайна. Криві Безьє, раціональні кубічні сплайни, Бета сплайни» - «Krzywe sklejane splines. Wielomiany Bernsteina - krzywe Beziera, algorytm de Casteljau. Krzywe B-sklejane (B-splinses)»; «Колірні моделі в комп'ютерній графіці» - «Przestrzenie barw w grafice RGB, CMY, (CMYK), HSV» і т. п.

Наголосимо, специфічною складовою формування компетентностей безпосередньо фахівців з кібербезпеки у процесі вивчення «Комп'ютерної графіки» має бути розгляд таких тем: формати та методи компресії цифрових образів, стеганографічні методи приховування інформації в сучасних графічних форматах, голографія і т. п. Нажаль, означена тематика розглядається тільки в польських планах підготовки фахівців (частково у навчальній програмі кафедри захисту інформації та кібербезпеки НУ ім. Тараса Шевченка) на рівні методів і форматів компресії зображень, а саме: «Алгоритми компресії з втратами та без втрат у комп'ютерній графіці. Основні графічні формати - JPG, GIF, PNG» («Algorytmy kompresji stratnej i bezstratnej w grafice komputerowej. Podstawowe formaty graficzne - JPG, GIF, PNG») та «Формати запису та компресії растрових образів (дискритизації образів і фільтрація) та засади математичного опису векторних образів» («Formaty zapisu i kompresji obrazów rastrowych (próbkowanie i filtracja) oraz zasady matematycznego opisu obrazów wektorowych»).

Нижче наведено загальну таблицю порівняльного аналізу тематик лабораторних або практичних занять і відповідної їм кількості годин 3 дисципліни «Інженерна та комп’ютерна графіка» для різних країн (табл. 3). 
Таблиия 3

\section{Порівняльний аналіз тематики лабораторних робіт 3 дисципліни «Інженерна та комп'ютерна графіка»}

\begin{tabular}{|c|c|c|c|c|c|c|c|}
\hline \multicolumn{2}{|l|}{ Україна } & \multicolumn{2}{|l|}{ Pociя } & \multicolumn{2}{|c|}{ Казахстан } & \multicolumn{2}{|l|}{ Польща } \\
\hline $\begin{array}{c}\text { Назва } \\
\text { лабораторної } \\
\text { роботи }\end{array}$ & $\begin{array}{l}\text { К-ть } \\
\text { год. }\end{array}$ & $\begin{array}{c}\text { Назва } \\
\text { лабораторної } \\
\text { роботи }\end{array}$ & $\begin{array}{l}\text { К-ть } \\
\text { год. }\end{array}$ & $\begin{array}{c}\text { Назва } \\
\text { лабораторної } \\
\text { роботи }\end{array}$ & $\begin{array}{l}\text { К-ть } \\
\text { год. }\end{array}$ & $\begin{array}{c}\text { Назва } \\
\text { лабораторної } \\
\text { роботи }\end{array}$ & $\begin{array}{l}\text { К-ть } \\
\text { год. }\end{array}$ \\
\hline $\begin{array}{l}\text { Обробка } \\
\text { растрових } \\
\text { зображжень. } \\
\text { Програма } \\
\text { растрової } \\
\text { графіки Adobe } \\
\text { PhotoShop. } \\
\text { Iнструменти }\end{array}$ & & 1 & - & 1 & & $\begin{array}{l}\text { Analiza } \\
\text { funkcjonalnosci } \\
\text { pakietu Adobe } \\
\text { Photoshop w } \\
\text { zakresie } \\
\text { podstawowych } \\
\text { zagadnień grafiki } \\
\text { komputerowej }\end{array}$ & 3 \\
\hline $\begin{array}{l}\text { Adobe } \\
\text { PhotoShop. } \\
\text { Швидка маска. } \\
\text { Модифікація }\end{array}$ & & - & - & - & & $\begin{array}{l}\text { Adobe Photoshop } \\
\text { - realizacja } \\
\text { podstawowych } \\
\text { transformacji }\end{array}$ & 3 \\
\hline $\begin{array}{l}\text { виділених } \\
\text { областей. }\end{array}$ & 12 & - & - & - & & $\begin{array}{l}\text { Adobe Photoshop } \\
\text { - krzywe Beziera }\end{array}$ & 3 \\
\hline $\begin{array}{l}\text { Використання } \\
\text { каналів. Робота } 3 \\
\text { шарами. }\end{array}$ & & - & - & - & & $\begin{array}{l}\text { Adobe Photoshop } \\
\text { - krzywe B- } \\
\text { sklejane }\end{array}$ & 3 \\
\hline $\begin{array}{l}\text { фикористання } \\
\text { фільтрів. } \\
\text { Корекція } \\
\text { кольору. } \\
\text { Градієнт. } \\
\text { Фільтрація } \\
\text { зображень }\end{array}$ & & - & - & - & & $\begin{array}{l}\text { Adobe Photoshop } \\
\text { - przestrzenie } \\
\text { barw w grafice }\end{array}$ & 3 \\
\hline- & - & - & - & - & & $\begin{array}{l}\text { Analiza } \\
\text { funkcjonalnosci } \\
\text { pakietu Autodesk } \\
\text { Softimage w } \\
\text { zakresie } \\
\text { podstawowych } \\
\text { zagadnień grafiki } \\
\text { komputerowej }\end{array}$ & 3 \\
\hline- & - & - & - & - & & $\begin{array}{l}\text { Autodesk } \\
\text { Softimage - } \\
\text { nakładanie } \\
\text { tekstur, } \\
\text { zagadnienia } \\
\text { mapowania } \\
\end{array}$ & 3 \\
\hline - & - & - & - & - & & $\begin{array}{l}\text { Autodesk } \\
\text { Softimage - } \\
\text { modelowanie } \\
\text { oświetlenia }\end{array}$ & 3 \\
\hline- & - & - & - & - & & $\begin{array}{l}\text { Autodesk } \\
\text { Softimage - } \\
\text { zagadnienia } \\
\text { globalnego } \\
\text { oświetlenia } \\
\text { (silniki } \\
\text { renderujące, } \\
\text { raytracing, } \\
\text { raradiosity) }\end{array}$ & 3 \\
\hline
\end{tabular}




\begin{tabular}{|c|c|c|c|c|c|c|c|}
\hline \multicolumn{2}{|l|}{ Україна } & \multicolumn{2}{|l|}{ Росія } & \multicolumn{2}{|c|}{ Казахстан } & \multicolumn{2}{|c|}{ Польща } \\
\hline $\begin{array}{c}\text { Назва } \\
\text { лабораторної } \\
\text { роботи }\end{array}$ & $\begin{array}{l}\text { К-ть } \\
\text { год. }\end{array}$ & $\begin{array}{c}\text { Назва } \\
\text { лабораторної } \\
\text { роботи }\end{array}$ & $\begin{array}{c}\text { К-ть } \\
\text { год. }\end{array}$ & $\begin{array}{c}\text { Назва } \\
\text { лабораторної } \\
\text { роботи }\end{array}$ & $\begin{array}{c}\text { К-ть } \\
\text { год. }\end{array}$ & $\begin{array}{c}\text { Назва } \\
\text { лабораторної } \\
\text { роботи }\end{array}$ & $\begin{array}{l}\text { К-ть } \\
\text { год. }\end{array}$ \\
\hline- & - & - & - & - & & $\begin{array}{l}\text { Autodesk } \\
\text { Softimage - } \\
\text { zastosowanie } \\
\text { algorytmów } \\
\text { cieniowania }\end{array}$ & 3 \\
\hline $\begin{array}{l}\text { Pобота в } \\
\text { редакторі } \\
\text { Adobe } \\
\text { Illustrator. } \\
\text { Програма } \\
\text { векторної } \\
\text { графіки Adobe } \\
\text { Illustrator }\end{array}$ & 8 & - & - & - & - & - & - \\
\hline $\begin{array}{l}\text { Iнтерфейс C·\# } \\
\text { (Poбота } 3 \\
\text { Windows Form). } \\
\text { Програмування } \\
\text { комп'ютерної } \\
\text { графіки. } \\
\text { Використання } \\
\text { графічних } \\
\text { бібліотек. } \\
\text { Інструменти. } \\
\text { Написання } \\
\text { програмного } \\
\text { коду на } \\
\text { побудови } \\
\text { графічних } \\
\text { зображень }\end{array}$ & 4 & $\begin{array}{l}\text { Iнтерфейс C·\# } \\
\text { / C++ Растрова } \\
\text { графіка. } \\
\text { Малювання } \\
\text { графіків } \\
\text { функцій } \\
\text { заданих явно, } \\
\text { неявно, } \\
\text { параметрично } \\
\text { Iнтерфейс C·\# } \\
\text { / C++ Сплайни. } \\
\text { Візуалізація } \\
\text { тривимірних } \\
\text { об'єктів, } \\
\text { центральне } \\
\text { проектування і } \\
\text { використання } \\
\text { сплайнів } \\
\text { Iнтерфейс C·\# } \\
\text { / C++ } \\
\text { Алгоритми } \\
\text { текстурування } \\
\text { і фільтрації. } \\
\text { Елементи } \\
\text { цифрової } \\
\text { обробки } \\
\text { зображень. } \\
\text { Фільтрація }\end{array}$ & 16 & - & - & - & - \\
\hline- & - & - & & $\begin{array}{l}\text { Знайомство із } \\
\text { системою } \\
\text { АutoСАD. } \\
\text { Налаштування } \\
\text { параметрів } \\
\text { креслення. } \\
\text { підготовка } \\
\text { робочого } \\
\text { середовища в } \\
\text { АutоСАD } \\
\text { Малювання } \\
\text { основних } \\
\text { графічних } \\
\text { об'єктів. } \\
\text { Об'єктна }\end{array}$ & 2 & - & - \\
\hline
\end{tabular}




\begin{tabular}{|c|c|c|c|c|c|c|c|}
\hline \multicolumn{2}{|c|}{ Україна } & \multicolumn{2}{|l|}{ Росія } & \multicolumn{2}{|c|}{ Казахстан } & \multicolumn{2}{|c|}{ Польща } \\
\hline $\begin{array}{c}\text { Назва } \\
\text { лабораторної } \\
\text { роботи } \\
\end{array}$ & $\begin{array}{l}\text { К-ть } \\
\text { год. }\end{array}$ & $\begin{array}{c}\text { Назва } \\
\text { лабораторної } \\
\text { роботи } \\
\end{array}$ & $\begin{array}{l}\text { К-ть } \\
\text { год. }\end{array}$ & $\begin{array}{c}\text { Назва } \\
\text { лабораторної } \\
\text { роботи } \\
\end{array}$ & $\begin{array}{l}\text { К-ть } \\
\text { год. }\end{array}$ & $\begin{array}{c}\text { Назва } \\
\text { лабораторної } \\
\text { роботи } \\
\end{array}$ & $\begin{array}{l}\text { К-ть } \\
\text { год. }\end{array}$ \\
\hline & & & & прив'язка & & & \\
\hline - & - & - & & $\begin{array}{l}\text { AutoCAD. } \\
\text { Використання } \\
\text { графічних } \\
\text { примітивів }\end{array}$ & 2 & - & - \\
\hline- & - & - & & $\begin{array}{l}\text { AutoCAD. } \\
\text { Побудова } \\
\text { графіків } \\
\text { функцій однієї } \\
\text { змінної }\end{array}$ & 2 & - & - \\
\hline - & - & - & & $\begin{array}{l}\text { AutoCAD. } \\
\text { Побудова } \\
\text { проекцій тіл }\end{array}$ & 4 & - & - \\
\hline - & - & - & & $\begin{array}{l}\text { AutoCAD. } \\
\text { Перетворення } \\
\text { зображень }\end{array}$ & 4 & - & - \\
\hline- & - & - & & $\begin{array}{l}\text { AutoCAD. } \\
\text { Растрові } \\
\text { алгоритми }\end{array}$ & 4 & - & - \\
\hline - & - & - & & $\begin{array}{l}\text { AutoCAD. } \\
\text { Заповнення } \\
\text { областей }\end{array}$ & 4 & - & - \\
\hline - & - & - & & $\begin{array}{l}\text { AutoCAD. } \\
\text { Відсікання } \\
\text { відрізків }\end{array}$ & 4 & - & - \\
\hline - & - & - & & $\begin{array}{l}\text { AutoCAD. } \\
\text { Видалення } \\
\text { невидимих } \\
\text { ліній і } \\
\text { поверхонь }\end{array}$ & 4 & - & - \\
\hline
\end{tabular}

У Росії і Казахстані перелік контенту лекційного матеріалу й у більшій мірі тематики лабораторних робіт $є$ відмінними від робочих програм Україна-Польща. Результати порівняльного аналізу з усією очевидністю доводять, що професійна підготовка IT бакалаврів 3 дисципліни «Комп'ютерна графіка» в пострадянських країнах спрямована на процес навчання за інженерно-технічною складовою. Підтвердженням цього $є$ тематики лабораторних занять та й сама назва дисциплін «Інженерна та комп'ютерна графіка»: робота тільки з Інтерфейсом C \# / C++ (Росія) або практичні тільки 3 програмним забезпеченням AutoCAD (Казахстан). У ВН3 Казахстану студентам профілю «Інформаційні системи» пропонується поглиблене вивчення дисципліни «Начертательная геометрия и компьютерная графика» 3 використанням приладних програмних продуктів у галузі проектування об'єктів різних класів або інформаційних систем.

Студенти з освітнього напряму IT кваліфікаційного рівня бакалавр усіх вище згаданих країн на основі вивчення дисципліни «Комп'ютерна графіка», зрозуміло мають і загальні базові складові вмінь, навичок та можливість здобути знання з різних видів 2D i 3D графіки, стандартів RGB, CMYK, HSB, а також практичних навичок 3 різного класу прикладного програмного забезпечення та ін.

Рівень вірогідності висновків підтверджується кількістю вищих навчальних закладів, навчально-методичне забезпечення яких було проаналізовано. Загалом 27-м вищих навчальних закладів, серед яких: Україна - 6, Польща - 9, Казахстан - 6, Росія 6. 


\section{3. ВИСНОВКИ ТА ПЕРСПЕКТИВИ ПОДАЛЬШИХ ДОСЛІДЖЕНЬ}

Проведене дослідження дає аргументовані підстави для визначення особливостей формування контенту навчальної дисципліни «Комп'ютерна графіка» 3 метою узгодження його складових відповідно груп професійних компетентностей майбутніх бакалаврів кібербезпеки. Виключно всі розглянуті плани і навчальні програми ВНЗ для підготовки висококваліфікованих кадрів рівня бакалавра, вивчаючи дисципліну «Комп'ютерна графіка», тією чи іншою мірою забезпечують систему формування фахових компетентностей для вирішення широкого спектра завдань. Однак, освітня діяльність кожної країни спрямована на свою систему стандартизації, нормативноправового i економічного забезпечення 3 урахуванням напрямів використання спеціалістів згідно потреб того чи іншого ринку праці і послуг.

Результати проведеного порівняльного аналізу контенту освітніх планів, навчальних i робочих програм вищих навчальних закладів України, Польщі, Казахстану та Росії можуть слугувати підгрунтям для визначення змісту навчальнометодичного комплексу 3 предмету «Комп'ютерна графіка». Перелік лекцій, практичних занять, програмного забезпечення, як доводить порівняльний аналіз вітчизняного і зарубіжного досвіду, має бути орієнтованим на розгляд таких тем: формати і методи компресії цифрових образів, стеганографічні методи приховування інформації в сучасних графічних форматах, голографія і т. п., що максимально сприятиме формуванню професійних компетентностей саме майбутніх бакалаврів кібербезпеки.

Перспективним напрямом подальших наукових розвідок вважаємо порівняльний аналіз стандартів навчання комп'ютерної графіки майбутніх бакалаврів кібербезпеки в країнах СС та США, а також обгрунтування теоретичних і методичних основ системної модернізації педагогічного процесу вищих навчальних закладів, у яких здійснюється підготовка бакалаврів кібербезпеки тощо.

\section{СПИСОК ВИКОРИСТАНИХ ДЖЕРЕЛ}

[1] N. Morze, O. Buinytska, "Open E-Environment - The Key Instrument Of The Education Quality", International Journal of Research in E-learning, №1 (1), p. 25-47, 2015.

[2] О. В.Матвійчук-Юдіна, "Інформаційні технології системи вищої освіти", Publishing house Education and Science, Dil 11, p. 9-5, 2009.

[3] "Industry models" [Электронный www.careeronestop.org/CompetencyModel/competency-models/pyramid-home.aspx .

[4] Навчальний план Politechnika Poznańska Kierunek : Informatyka Wydział Elektryczny [Электронный peсурс]. Доступно: http://fee.put.poznan.pl/images/stories/studia/pdf/2014_2015/INF_st1_2014_cz2.pdf

[5] О.В.Матвійчук-Юдіна, "Ключові компетентності фахівців спеціальності „Кібербезпека” 3 предмету „Комп’ютерна графіка” згідно індустріальної моделі промисловості", Вісник Житомирського держсвного університету. Педагогічні науки, № 4 (90), С. 93-98, 2017.

[6] Навчальний план Казахського національного технічного університету ім. К. Сатпаєва. [Электронный ресурс]. Доступно: http://portal.kazntu.kz/files/speciality/5B070300.pdf

[7] Навчальний план Новосибірського державного університету. [Электронный ресурс]. Доступно: http://nsu.ru/6cf8ba10a201725cb6ef32b060110dcb

[8] Навчальний план Казахського національного технічного університету ім.. К. Сатпаєва. [Электронный ресурс]. Доступно: http://portal.kazntu.kz/files/speciality/5B070300.pdf

[9] O. V. Matviychuk-Judina, "Comperetive analysis of modern methods of e-learning of computer graphics for IT industry bachelors, Inżynier XXI wieku": VI Międzynarodowa Konferencja Studentów oraz Doktorantów, Bielsko-Biala, 2016, pp.195-200. 


\title{
ОТЕЧЕСТВЕННЫЙ И ЗАРУБЕЖНЫЙ ОПЫТ ФОРМИРОВАНИЯ СОДЕРЖАНИЯ ОБУЧЕНИЯ КОМПЬЮТЕРНОЙ ГРАФИКЕ БУДУЩИХ БАКАЛАВРОВ КИБЕРБЕЗОПАСНОСТИ
}

\author{
Матвийчук-Юдина Елена Васильевна \\ старший преподаватель, соискатель кафедры компьютерных мультимедийных технологий \\ Национальный авиационный университет, г. Киев, Украина \\ ORCID ID 0000-0002-5906-5023 \\ metalen3@ukr.net
}

\begin{abstract}
Аннотация. В статье определены и проанализированы особенности формирования содержания учебной дисциплины «Компьютерная графика»в процессе профессиональной подготовки бакалавров кибербезопасности. Осуществлен сравнительный анализ контента учебных планов, учебных и рабочих программ подготовки бакалавров кибербезопасности высших учебных заведений Украины, Польши, Казахстана и России. Результаты анализа мирового опыта свидетельствуют, что подготовка высококвалифицированных кадров уровня бакалавра в той или иной мере ориентирована на создание благоприятных условий для формирования профессиональных компетентностей для решения широкого спектра производственных заданий, несмотря на то, что образовательная деятельность каждой страны опирается на собственную систему стандартизации, нормативно-правового и экономического обеспечения с учетом направлений использования специалистов согласно потребностей рынка труда и услуг. Результаты исследования могут служить основой для определения содержания учебно-методического комплекса по предмету «Компьютерная графика», ориентированного на рассмотрение следующих тем: форматы и методы компрессии цифровых образов, стеганографические методы защиты информации в современных графических форматах, голография и т. п., изучение которых в максимальной степени будет содействовать формированию профессиональных компетентностей будущих бакалавров кибербезопасности.
\end{abstract}

Ключевые слова: контент учебно-методического комплекса; учебная программа; профессиональные компетентности; интегрированная компетентность; специалисты по информационным технологиям и кибербезопасности; компьютерная графика.

\section{DOMESTIC AND FOREIGN EXPERIENCE OF THE CONTENT FORMATION OF COMPUTER GRAPHICS EDUCATION FOR FUTURE BACHELORS OF CYBERSECURITY}

\author{
Olena V. Matviiczuk-Yudina \\ senior lecturer; research worker; Department of computer multimedia technologies \\ National Aviation University, Kyiv, Ukraine \\ ORCID ID 0000-0002-5906-5023 \\ metalen3@ukr.net
}

Abstract. The article defines and analyzes the peculiarities of the formation of the content of the
academic discipline "computer graphics" in the process of professional training of bachelors in
cyber security. A detailed comparative analysis of the content of educational plans, training and
work programs for the preparation of bachelor's degrees in cyber-security of higher educational
institutions in Ukraine, Poland, Kazakhstan, and Russia has been carried out. The analysis of the
world experience shows that the training of highly skilled bachelor level individuals is more or
less focused on the creation of favorable conditions for the formation of professional competencies
for solving a wide range of production tasks. Despite the fact that educational activity of each
country is based on its own system of standardization, legal and economic support take into
account the directions of using specialists in accordance with the needs of a particular labor market
and services. The results of the study can serve as the fundamental basis for determining the
content of the methodological educational complex for the subject "computer graphics", that
should be focused on the consideration of the following topics: formats and methods of
compression of digital images, steganographic methods of information protection in modern 
graphic formats, holography, etc., that will significantly contribute to the formation of professional competences of future Bachelors of Cyber Security.

Key words: content of educational-methodical complex; curriculum; professional competencies; integrated competence; information technology and cyber security specialists; computer graphics.

\section{REFERENCES (TRANSLATED AND TRANSLITERATED)}

[1] Morze N, Buinytska O. Open E-Environment - The Key Instrument Of The Education Quality, International Journal of Research in E-learning, №1 (1), p. 25-47, 2015. (in English)

[2] Matviychuk-Yudina O. V. Information Technologies of the Higher Education System, Publishing house Education and Science, Dil. 11, pp. 9-15, 2009. (in Ukrainian)

[3] Industry models. [Online]. Available: https://www.careeronestop.org/CompetencyModel/competencymodels/pyramid-home.aspx. (in English)

[4] Curriculum of the Politechnika Poznańska Kierunek: Informatyka Wydział Elektryczny [Online]. Available: http://fee.put.poznan.pl/images/stories/studia/pdf/2014_2015/INF_st1_2014_cz2.pdf. (in Polish)

[5] Matviychuk-Yudina O.V. Key competencies of specialists in the specialty "Cyber security" on the subject "Computer graphics" according to the industrial model of industry, Bulletin of Zhytomyr State University, No. 4 (90), pp. 93-98, 2017. (in Ukrainian)

[6] Curriculum of the Kazakh National Technical University named after K. Satpaev. [Online]. Available: http://portal.kazntu.kz/files/speciality/5B070300.pin Kazakhdf. (in Kazakh)

[7] Curriculum of the Novosibirsk State University. [Online]. Available: http://nsu.ru/6cf8ba10a201725cb6ef32b060110dcb. (in Russian)

[8] Curriculum of the Kazakh National Technical University named after K.Satpaev. [Electronic resource]. Access mode: http://portal.kazntu.kz/files/speciality/5B070300.pdf. (in Kazakh)

[9] Matviychuk-Yudina, O.V. Comperetive analysis of computer-generated graphics for IT industry bachelors, Inżynier XXI wieku: VI Międzynarodowa Conference of Students and Doctoral Students, Bielsko-Biała, pp. 195-200, 2016. (in English)

\section{(cc) BY-NC-SA}

This work is licensed under Creative Commons Attribution-NonCommercial-ShareAlike 4.0 International License. 